\title{
Financial Soundness Of Selected Indian Petroleum Companies Using Altman Z - Score Model
}

\author{
T.Srinivas
}

Bheema Institute Of Technology \& Science, Adoni, India

\begin{abstract}
Its need an hour to know the performance of Oil companies namely Indian Oil Corporation, Hindustan Petroleum Corporation Limited, Bharat Petroleum because market is having highly volatility, through A predictive model created by Edward Altman Z score in the 1960's. This model consists of different financial ratios to ascertain the likelihood of bankruptcy. The present study intends to analyze the financial health of selected oil companies through the application of altman $\mathrm{z}$ score model. It is found that the financial health of the selected companies under study is Bharat petroleum corporation is relatively better than Indian oil corporation and Hindustan petroleum.
\end{abstract}

Keywords: Z - Score analysis, Financial Health, Bankruptcy, Bharat Petroleum Corporation, Indian Oil Corporaton, Hindustan Petroleum

\section{Introduction}

The backbone of any organization is financially sound. It means how they are procuring the funds and utilizing the same funds in a effective utilization. Therefore continuous monitoring is required to take corrective measures to meet the short term and long term requirements adequately.

Any financial statements are the source of information to the investors based on which the financial planning and decision making would takes places. The financial statements consist of profit \& loss account and balance sheet. The Profit \& loss Account provides data about operating activities of the business concern and it projects the profit \& loss of the business. Where as balance sheet gives the information about the assets $\&$ liabilities of the business ${ }^{[1]}$.

Through this source only we would assess the company's strengths \& weakness. Due to this only the pivotal decisions would take places through financial ratios. A single ratio or few ratios we could not take the financial decisions. It doesn't serve our purpose ${ }^{[2]}$.

Therefore Altman $\mathrm{Z}$ score consisting of different financial ratios in one equation i.e

\section{$Z=1.2 \times 1+1.4 \times 2+3.3 \times 3+0.6 \times 4+0.99 \times 5$}

$\mathrm{X} 1=$ Working Capital/Total assets

$\mathrm{X} 2=$ Retained Earnings/Total assets

$\mathrm{X} 3=$ Earnings before interest and taxes/Total assets

$\mathrm{X} 4=$ Market value of share/Total assets

$\mathrm{X} 5=$ Sales/Total assets

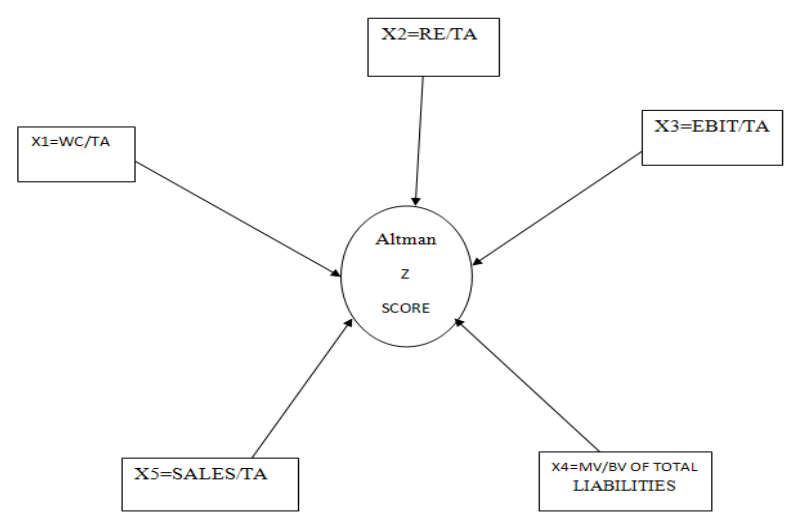

Variable used in $\mathbf{Z}$ score analysis:

The following variables (accounting ratio) has taken as variables to combine them into single index i.e., Altman $\mathrm{Z}$ score analysis which measure the efficiency in envisaging the bankruptcy.

$\mathrm{X} 1$ :-It measures the relationship between working capital to total assets(WC/TA).This ratio measures of the net liquid assets of a business concern.

X2:-It measures the relationship between retained earnings/ total assets. It indicates profitability to the firm size.

$\mathrm{X} 3$ :-It is proportion of earnings before interest and taxes total assets(EBIT/TA).It says that how much firm has earned before interest and taxes out off total assets.

X4:-It measures the relationship of market value of equity to book value of total liabilities. It gives the market's view of the company relative to the total liabilities. It measures how much 
assets of an firm can decline in value before the liabilities exceed the assets and the concern becomes insolvent.

X5:-It shows the relationship of sales to total assets(SA/TA). The assets turnover ratio is a standard financial measure for illustrating the sales generating capacity of the assets ${ }^{[3]}$.

\begin{tabular}{|c|c|c|c|}
\hline \multicolumn{4}{|c|}{ Standard Z Score Parameters } \\
\hline Situation & $\begin{array}{l}Z \text { score } \\
\text { Value }\end{array}$ & Zones & Verdict \\
\hline 1 & Below 1.8 & Bankruptcy Zone & $\begin{array}{l}\text { Failure is } \\
\text { certain }\end{array}$ \\
\hline II & $1.8-2.99$ & Healthy zone & $\begin{array}{l}\text { Uncertain } \\
\text { to predict }\end{array}$ \\
\hline III & Above 2.99 & Too Healthy zone & Not to fall. \\
\hline
\end{tabular}

Objectives of the study:

1. This research paper study attempts to assess the financial performance of selected petroleum companies namely Indian oil corporation, Bharat Petroleum corporation limited, Hindustan petroleum by using the Altman $\mathrm{Z}$ score analysis

2. To know the contribution of individual ratio on $\mathrm{Z}$ index (Relative difference)

The study is completely descriptive and analytical. The $\mathrm{Z}$ index for a period of six years (2010-2011to 2015-16) has been calculated for 3 petroleum companies namely Bharat petroleum, Indian Oil Corporation, Hindustan petroleum, were included in the study(see appendix). Data has been gathered for 6 years (2010-11 to 2015-2016) from secondary sources such as annual reports of companies ${ }^{[4]}$.

\section{Calculation of $x 1, x 2, x 3, x 4, x 5, \&$ z values of Bharat petroleum corporation limited}

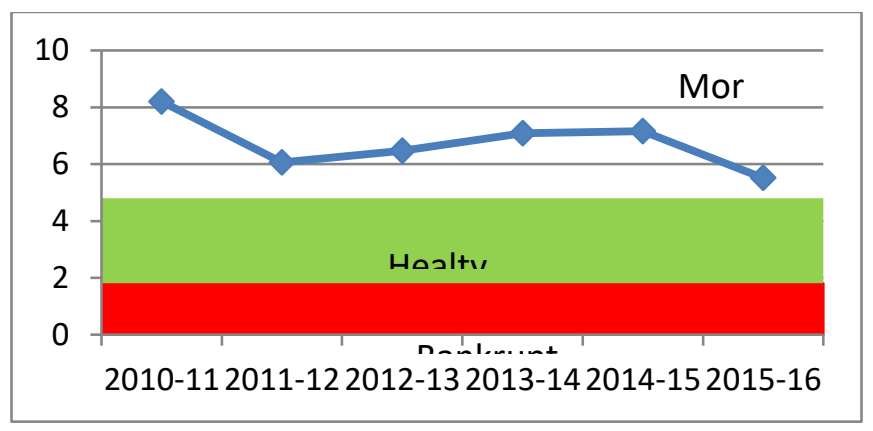

Petroleum Corporation Limited had drastic changes since 2010-11; 0.751355, for the next subsequent years are $0.34223,0.32908,0.22625,0.02451,0.02707$.

It means that in the year 2010-2011 the company has following conservative current policy for the next years it has switch over to aggressive current policy.

X2=Retained Earnings $\div$ Total Assets:- It has been observed that retained earnings to total assets of Bharat Petroleum Corporation Limited is in the year 2010-11; 0.122335 for the next 5 years are $0.076231 ; 0.091519 ; 0.1036 ; 0.149029$; 0.145065

It means that from 0.122 falls down to 0.076 in the year 2011 12 relatively it has increases to 0.091 in the year 2012-13 for the next years consistently it has increasing i.e 0.10364 ; 0.14903; slightly it has falls down last year i.e 2015-16 0.14506 .

There may be more chances are there to borrow the amount from outside if the retained earnings to total assets are decreases.

X3=Earnings Before Interest \& Taxes $\div$ Total Assets :- It has been found that EBIT to total assets of Bharat Petroleum Corporation Limited has been increasing since 2010-11;

\begin{tabular}{cccccccc}
\hline VARIABLES & X1 & \multicolumn{1}{c}{ X2 } & \multicolumn{1}{c}{ X3 } & \multicolumn{1}{c}{ X4 } & X5 & $\begin{array}{c}\mathbf{Z} \\
\text { values }\end{array}$ \\
& & & & & & & \\
\hline $\mathbf{2 0 1 0 - 2 0 1 1}$ & 0.75135 & 0.12234 & 0.10649 & 0.01542 & 6.83722 & 8.20241 \\
$\mathbf{2 0 1 1 - 2 0 1 2}$ & 0.34223 & 0.07623 & 0.14002 & 0.01233 & 5.12561 & 6.06121 \\
$\mathbf{2 0 1 2 - 2 0 1 3}$ & 0.32908 & 0.09152 & 0.18269 & 0.00929 & 5.39111 & 6.46866 \\
$\mathbf{2 0 1 3 - 2 0 1 4}$ & 0.22625 & 0.10364 & 0.22557 & 0.0067 & 5.98423 & 7.08937 \\
$\mathbf{2 0 1 4 - 2 0 1 5}$ & 0.02451 & 0.14903 & 0.26005 & 0.0137 & 6.12222 & 7.16542 \\
$\mathbf{2 0 1 5 - 2 0 1 6}$ & 0.02707 & 0.14506 & 0.26536 & 0.01759 & 4.4353 & 5.51274 \\
\hline
\end{tabular}
0.106492 for the next years are $0.14002,0.18269,0.22557,0.26005$, 0.26536

It is quite apparent that the firm's profits has been increasing since 2010-11

X4=Market Value of Equity $\div$ Book Value of Total Liabilities.:- It has been found that the Market Value Of Equity $\div$ Total Assets of Bharat Petroleum Corporation Limited is gradually decreasing since 2010-11, 0.01542 and the next year ratios are

Calculation of Regressor, \& $\mathrm{z}$ values of Bharat petroleum corporation limited.

\section{Intrepretation:}

X1= working capital $\div$ Total Assets:-It has been observed that the working capital to total assets of Bharat as follows $0.01233,0.00929,0.0067,0.0137,0.01759$.After 2011-12 it has continuously falls down again it gets recovery in the year 2014-15 0.0137 2015-16 0.01759 respectively.

The higher the value it is better s ratio

X5=Sales -Total Assets:- It has found that the sales to total assets of Bharat Petroleum Corporation Limited gradually it is increasing except in the last year 2015-16.The ratios in the 
year 2010-11 us 6.83722 and the next years are as follows $5.12561 ; 5.39111 ; 5.98423 ; 6.12222 ; 4.4353$ decreasing. It is significantly less than the most other variables.

X2=Retained Eanings $\div$ Total Assets:- In the above graph

\begin{tabular}{|c|c|c|c|c|c|c|}
\hline \multicolumn{7}{|c|}{$\begin{array}{l}\text { Contribution of individual ratios of Bharat Petroleum Corporation Limited } \\
\text { On Z score Analysis by using the Relative Difference }\end{array}$} \\
\hline Year & $2010-11$ & $2011-12$ & $2012-13$ & 2013-14 & $2014-15$ & $2015-16$ \\
\hline $\mathrm{X} 1=\mathrm{WC} \div \mathrm{TA}$ & 0.75135 & 0.34223 & 0.32908 & 0.22625 & 0.02451 & 0.02707 \\
\hline RD OF X1 & & -0.657766 & -0.670921 & -0.773749 & -0.975492 & -0.972932 \\
\hline $\mathrm{X} 2=\mathrm{RE} \div \mathrm{TA}$ & 0.12234 & 0.07623 & 0.09152 & 0.10364 & 0.14903 & 0.14506 \\
\hline RD OF X2 & & -0.923769 & -0.908481 & -0.896364 & -0.850971 & -0.854935 \\
\hline $\mathrm{X} 3=\mathrm{EBIT} \div \mathrm{TA}$ & 0.10649 & 0.14002 & 0.18269 & 0.22557 & 0.26005 & 0.26536 \\
\hline RD OF X3 & & -0.859984 & -0.817314 & -0.774433 & -0.739953 & -0.734644 \\
\hline $\mathrm{X} 4=\mathrm{MVE} \div \mathrm{TA}$ & 0.01542 & 0.01233 & 0.00929 & 0.0067 & 0.0137 & 0.01759 \\
\hline RD OF X4 & & -0.987675 & -0.990711 & -0.9933 & -0.986303 & -0.982409 \\
\hline $\mathrm{X} 5=\mathrm{SALES} \div \mathrm{TA}$ & 6.83722 & 5.12561 & 5.39111 & 5.98423 & 6.12222 & 4.4353 \\
\hline $\mathrm{Rd}$ of X5 & & -0.2505 & 0.051799 & 0.110018 & 0.023059 & -0.2755 \\
\hline
\end{tabular}

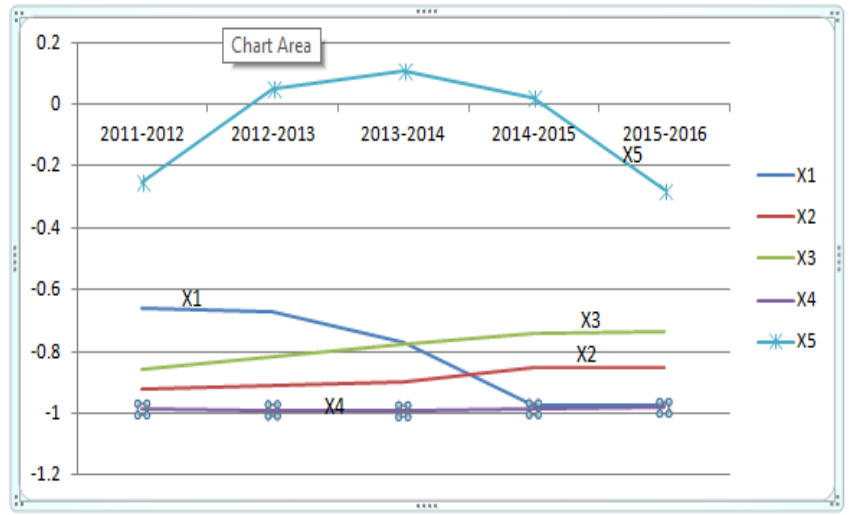

Figure: Interpretation Of Individual Ratios Of Bharat Petroleum Corporation Limited By Using The Relative Difference

\begin{tabular}{lllllll}
\hline VARIABLES & X1 & X2 & X3 & X4 & X5 & $\begin{array}{c}\mathbf{Z} \\
\text { values }\end{array}$ \\
& & & & & & \\
\hline $\mathbf{2 0 1 0 - 2 0 1 1}$ & 0.115008 & 0.01627 & 0.05319 & 0.00887 & 2.34478 & 2.66296 \\
$\mathbf{2 0 1 1 - 2 0 1 2}$ & -0.08354 & 0.00811 & 0.04723 & 0.00619 & 2.64572 & 2.68995 \\
$\mathbf{2 0 1 2 - 2 0 1 3}$ & -0.066 & 0.00757 & 0.04582 & 0.00513 & 2.70877 & 2.76738 \\
$\mathbf{2 0 1 3 - 2 0 1 4}$ & 0.0571 & 0.01443 & 0.05094 & 0.00386 & 2.99296 & 3.22218 \\
$\mathbf{2 0 1 4 - 2 0 1 5}$ & 0.05779 & 0.02568 & 0.07209 & 0.00936 & 3.21331 & 3.52999 \\
$\mathbf{2 0 1 5 - 2 0 1 6}$ & 0.00993 & 0.03486 & 0.09051 & 0.01485 & 2.80604 & 3.14629 \\
\hline
\end{tabular}

X1=Working Capital $\div$ Total Assets:- $\quad$ In the above graph that the $\mathrm{X} 1$ contribution on $\mathrm{Z}$ score index is gradually it has depicted that $\mathrm{X} 2$ contribution on $\mathrm{Z}$ score index is significantly better than the other variables.

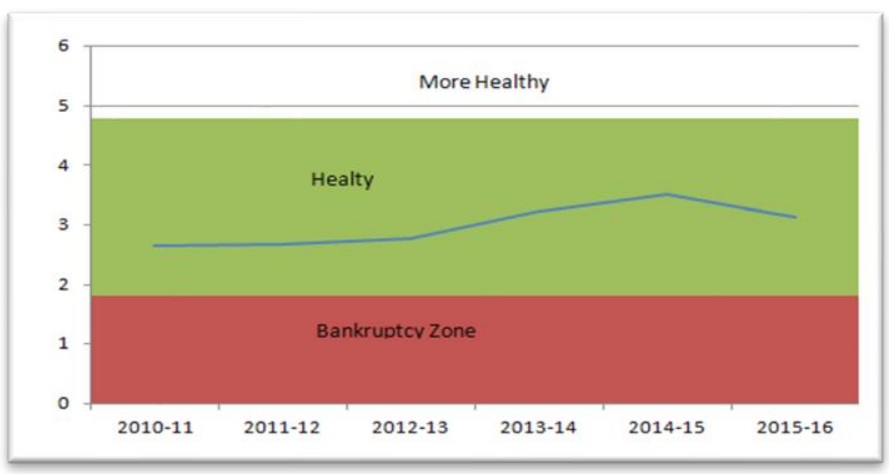

Figure: $z$ values graph of hindustan petroleum limited.

X3=EBIT $\div$ Total Assets:- In the above graph it has found that $\mathrm{X} 3$ contribution of $\mathrm{z}$ score index is significantly better that the remaining variables that is $\mathrm{X} 1, \mathrm{X} 2, \mathrm{X} 4$.

X4=Market Value $\div$ Book Value of Total Liabilities:- In the above graph it remains constant for the year 2011-12 to 2014-15 slightly it gets increases after 2014-15.

X5=Sales $\div$ Total assets:- sales $\div$ Total Assets ratio gets negative in the year 2011-12 for the next years slightly it gets increases. Last year it falls down to negative. It indicates that the production is not upto the mark.

Interpretation:-

X1=Working Capital $\div$ Total Assets:- It has been found that the working capital to total assets of Hindustan Petroleum 
Limited is decreasing since 2010-11, in the year 2010-2011 ratio is 0.115008 , and the next subsequent years are $0.008113,-0.66, \quad 0.057098, \quad 0.057794, \quad 0.009929$. The company is implementing aggressive current policy.

X2=Retained Earnings $\div$ Total Assets:- It has been observed that the retained earnings to total assets of Hindustan petroleum Limited are drastically decreasing since 2010-2011 is 0.0163 and the next subsequent years are 0.008, 0.007, $0.014,0.02,0.03$ respectively.

There are more chances are there if the retained earnings to total assets ratios are decreasing year by year it means that they are borrowing the amount from outside .

X3= Earnings Before Interest \& Taxes Total Assets: - It has been found that the EBIT/Total assets ratio of Hindustan Petroleum Limited are quite similar with minute changes.

X4=Market Value of the Share $\div$ Book Value of total liabilities: - It has been observed that the market value of the share/book value of total liabilities has been decreasing from 2010-11 to 2013-14 again it has increase for the next consecutive years

X5=Sales -Total assets: - It has found that the sales to total assets ratio gradually increasing since 2010-2011. In the year 2015-16 it has decreases by $12 \%$. It means that effective utilization of assets for the production purposes.
$0.00294,-0.00396,-0.03909$. The Company is maintaining aggressive current policy.

X2=Retained Earnings $\div$ Total Assets:- It has been found that the ratio of X2 of Indian Oil Corporation. In the year 2010-2011 the ratio is 0.01627 and the next subsequent years are decreasing $0.00811,0.00757$, and thereby remaining years are increasing $0.02568,0.03486$.

X3=Earnings Before Interest \& Taxes $\div$ Total Assets:- It has been found the EBIT $\div$ Total assets of Indian Oil Corporation is increasing since 2010-2011 i.e., 0.05319, and the remaining subsequent years are as follows 0.04723, 0.04582, 0.05094, 0.07209 respectively.

X4=Market Value of Equity $\div$ Total book value of liabilities:- It has observed that the ratio of X4 of Indian Oil Corporation is gradually decreasing continuously 4 years since 2010-2011 to 2013-2014 i.e., $0.01542,0.01233,0.00929,0.0067$ respectively. After that it has slightly increases continuously two years i.e., $0.0137,0.01759$ respectively.

X5=Sales -Total Assets:- It has been found that the X5 ratio of Indian Oil Corporation is continuously increasing since i.e, 2010-2011 1.74114 and the next subsequent years are $1.898776 ; 1.996008 ; 1.87474 ; 1.990117 ; 1.547184$ respectively it means the utilizing the assets very effectively.s

\begin{tabular}{|c|c|c|c|c|c|c|}
\hline \multicolumn{7}{|c|}{$\begin{array}{l}\text { Contribution of individual ratios of Bharat Petroleum Corporation Limited } \\
\text { On Z score Analysis by using the Relative Difference }\end{array}$} \\
\hline Year & $2010-11$ & $2011-12$ & $2012-13$ & 2013-14 & $2014-15$ & $2015-16$ \\
\hline $\mathrm{X} 1=\mathrm{WC} \div \mathrm{TA}$ & 0.115008 & -0.08354 & -0.066 & 0.057098 & 0.057794 & 0.009929 \\
\hline RD OF X1 & & -1.08354 & -1.066 & -0.942902 & -0.942206 & -0.990071 \\
\hline $\mathrm{X} 2=\mathrm{RE} \div \mathrm{TA}$ & 0.0162629 & 0.008113 & 0.007567 & 0.014433 & 0.02568 & 0.03486 \\
\hline RD OF X2 & & -0.991887 & -0.992433 & -0.985567 & -0.97432 & -0.96514 \\
\hline $\mathrm{X} 3=\mathrm{EBIT} \div \mathrm{TA}$ & 0.053189 & 0.047231 & 0.045825 & 0.050941 & 0.07209 & 0.090508 \\
\hline RD OF X3 & & -0.952769 & -0.954175 & -0.949059 & -0.92791 & -0.909492 \\
\hline $\mathrm{X} 4=\mathrm{MVE} \div \mathrm{TA}$ & 0.008873 & 0.006195 & 0.005134 & 0.003865 & 0.009356 & 0.014848 \\
\hline RD OF X4 & & -0.993805 & -0.994866 & -0.996135 & -0.990644 & -0.985152 \\
\hline $\mathrm{X} 5=\mathrm{SALES} \div \mathrm{TA}$ & 2.343777 & 2.645721 & 2.708769 & 2.992963 & 3.213309 & 2.80604 \\
\hline Rd of X5 & & 1.645721 & 1.708769 & 1.992963 & 2.213309 & 1.80604 \\
\hline
\end{tabular}

\section{Interpretation:-}

The interpretation of $\mathrm{X} 1, \mathrm{X} 2, \mathrm{X} 3, \mathrm{X} 4$ are not contributing on $\mathrm{Z}$ index value. Its quite apparent from the diagram more or less its contribution is same.

X5=Sales -Total Assets:- It has been found that sales to total assets are gradually increasing since 2010-2011 2.343777 and the next subsequent years are 2.645721, $2.708769,2.992963,3.213309$ and the last year is i.e.,20152016 is 2.80604 . It is quite clear that for production maximum utilization Interpretations:-

X1=Working Capital -Total Assets:- It has been observed that the $\mathrm{X} 1$ ratio of Indian Oil Corporation is decreasing. In the year 2010-2011 the ratio of X1 is 0.138213 and the next subsequent years are $0.005599,0.018594,0.018594,-$

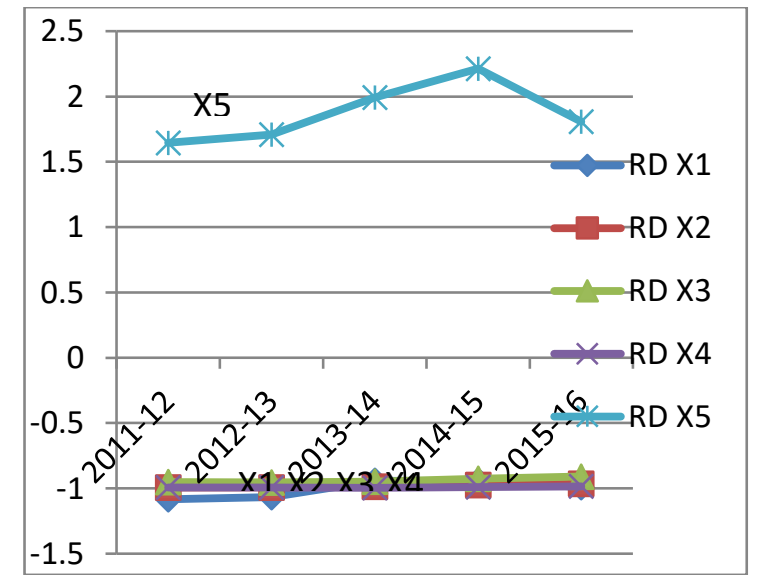


Interpretation Of Individual Ratios Of Hindustan Petroleum Corporation Limited By Using The Relative Difference

Calculation of $x 1, x 2, x 3, x 4, x 5$ and $z$ values of indian oil corporation limited

Interpretation Of Individual Ratios Of Indian Oil Corporation Limited By Using The Relative Difference
The interpretation of $\mathrm{X} 1, \mathrm{X} 2, \mathrm{X} 3, \mathrm{X} 4$ are not contributing on $\mathrm{Z}$ index value. Its quite apparent from the diagram more or less its contribution is same.

X5=Sales -Total Assets:- It has been observed that the X5 ratio's relative difference of Indian Oil Corporation is contributing much more than the other variables on $\mathrm{Z}$ index. In the

Year 2011-2012 X5 ratio's relative differences is 0.898776 and the next subsequent years

\begin{tabular}{|c|c|c|c|c|c|c|c|}
\hline VARIABLES & $\mathbf{X 1}$ & $\mathbf{X} 2$ & $\mathbf{X} 3$ & $\mathbf{X} 4$ & X5 & $Z$ values & $\begin{array}{l}\text { are as follows } 0.996008 \text {, } \\
0.87474,0.990117 \text {, last year } \\
\text { i.e., } 0.547184 \text { its contributing is } \\
\text { less than the previous years. }\end{array}$ \\
\hline 2010-2011 & 0.138213 & 0.027513 & 0.067754 & 0.003095 & 1.744114 & 2.156493 & Interpretation Of Individus \\
\hline 2011-2012 & 0.005599 & 0.012137 & 0.081254 & 0.001908 & 1.898776 & 2.172782 & Corporation \\
\hline 2012-2013 & 0.018594 & 0.014482 & 0.053827 & 0.00221 & 1.996008 & 2.197591 & Using The Relative \\
\hline 2013-2014 & -0.00294 & 0.018018 & 0.052545 & 0.001359 & 1.87474 & 2.0519 & Difference \\
\hline 2014-2015 & -0.00396 & 0.015215 & 0.044403 & 0.002204 & 1.990117 & 2.134618 & \\
\hline 2015-2016 & -0.03909 & 0.02789 & 0.07712 & 0.002586 & 1.547184 & 1.779894 & \\
\hline
\end{tabular}
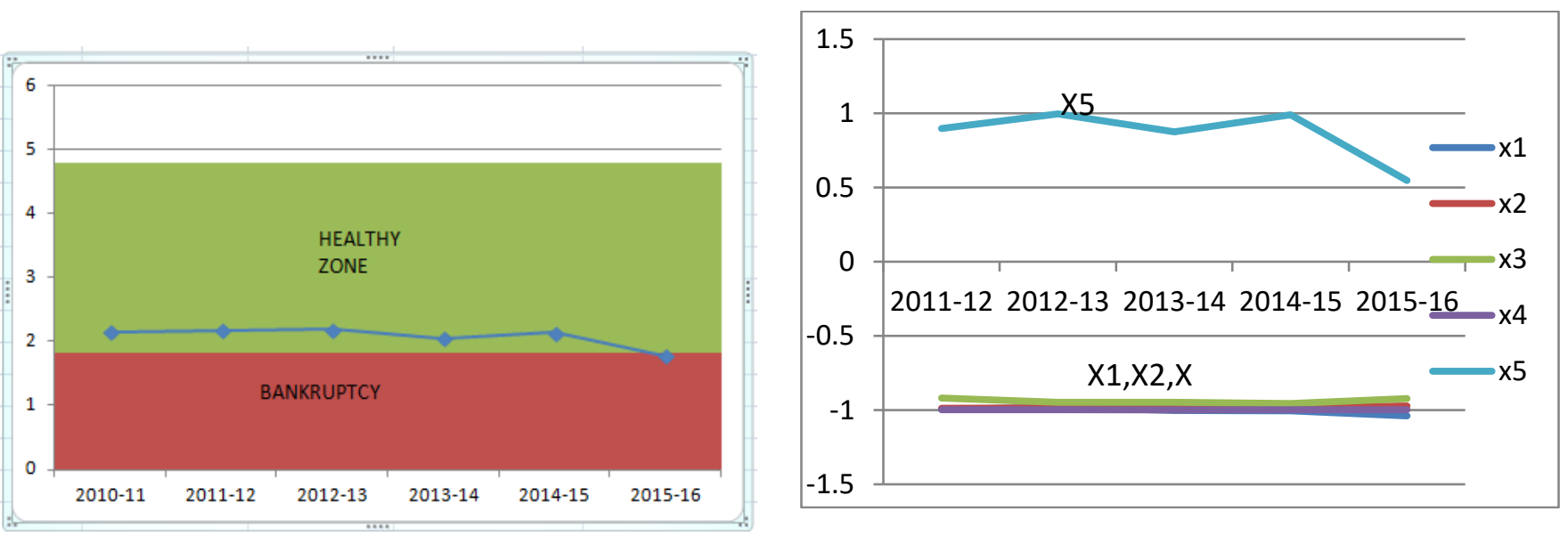

\begin{tabular}{|c|c|c|c|c|c|c|}
\hline \multicolumn{7}{|c|}{$\begin{array}{c}\text { Contribution Of Individual ratios Of Indian Oil Corporation on Z Score analysis by Using the relative } \\
\text { difference }\end{array}$} \\
\hline Year & $2010-11$ & 2011-12 & $2012-13$ & 2013-14 & $2014-15$ & $2015-16$ \\
\hline $\mathrm{X} 1=\mathrm{WC} \div \mathrm{TA}$ & 0.138213 & 0.005599 & 0.018594 & -0.00294 & -0.00396 & -0.03909 \\
\hline RD OF X1 & & -0.994401 & -0.981406 & -1.00294 & -1.00396 & -1.03909 \\
\hline $\mathrm{X} 2=\mathrm{RE} \div \mathrm{TA}$ & 0.027513 & 0.012137 & 0.014482 & 0.018018 & 0.015215 & 0.02789 \\
\hline RD OF X2 & & -0.987863 & -0.985518 & -0.981982 & 0.984785 & -0.97211 \\
\hline $\mathrm{X} 3=\mathrm{EBIT} \div \mathrm{TA}$ & 0.067754 & 0.081254 & 0.053827 & 0.052545 & 0.044403 & 0.07712 \\
\hline RD OF X3 & & -0.918746 & -0.946173 & -0.947455 & -0.955597 & -0.92288 \\
\hline $\mathrm{X} 4=\mathrm{MVE} \div \mathrm{TA}$ & 0.003095 & 0.001908 & 0.00221 & 0.001359 & 0.002204 & 0.002586 \\
\hline RD OF X4 & & -0.998092 & -0.99779 & -0.998641 & -0.997796 & -0.997414 \\
\hline X5=SALES $\div$ TA & 1.744114 & 0.898776 & 1.996008 & 1.87474 & 1.990117 & 1.547184 \\
\hline $\mathrm{Rd}$ of $\mathrm{X} 5$ & & 1.898776 & 0.996008 & 0.87474 & 0.990117 & 0.547184 \\
\hline
\end{tabular}

\section{Interpretations:-}

\section{Conclusion:-}

1.It has concluded that the Bharat Petroleum Corporation Limited relative difference variables are as follows $\mathrm{X} 1$ is 
gradually decreasing. $\mathrm{X} 2$ is slightly less contributing then $\mathrm{X} 1$, $\mathrm{X} 3 . \mathrm{X} 3$ is slightly more contributing than $\mathrm{X} 2 \& \mathrm{X} 4 . \mathrm{X} 4$ is constant through the period of study it does not contributed on $\mathrm{Z}$ index Value. $\mathrm{X} 5$ is relatively more contributing than remaining variables.

2. It has concluded that the relative difference variables $\mathrm{X} 1, \mathrm{X} 2, \mathrm{X} 3, \mathrm{X} 4$, are not much contributing on $\mathrm{Z}$ index value. It remains constant through the period of study. $X 5$ is contributing on $\mathrm{Z}$ index value.

3 . It has concluded that the relative difference variable $\mathrm{X} 1, \mathrm{X} 2, \mathrm{X} 3, \mathrm{X} 4$ are not much contributing on $\mathrm{Z}$ index value it remains constant. $\mathrm{X} 5$ is contributing more than the other variables.

The over all conclusion of the study says that all the variables are contributing on $\mathrm{Z}$ index value only in Bharat Petroleum Corporation Limited may be due to some internal factors in the company.

\section{References}

[1]. Edward, I, Altman(1968) "Financial ratios, Discriminant Analysis and prediction corporate Bankruptcy”, Journal of Finance, Volume 9 PP 589609.

[2]. Dr.M.Selvam \& S.vanitha \& M.Babu in their paper predicted the financial health and viability of India cements Ltd., They concluded that the cement company under the study was just on the range of financial collapse.

[3]. Chakraborty.P.K.(2006) Working capital management. A case study of Cadila Health Care Limited." Towards better working capital management. Murthy G.K. eds, Hyderabad India. The ICFAI University Press.

[4]. Pandey I.M. Financial Management Vikas Publication House. Eleventh Edition. 